\title{
Letter \\ Growth arrest-specific protein 6 (GAS6) and the protein C pathway
} Shi-Sheng Li

Department of Molecular and Experimental Medicine, The Scripps Research Institute, 10550 North Torrey Pines Road, La Jolla, CA 92037, USA

Corresponding author: Shi-Sheng Li, sshli@scripps.edu

Published: 18 April 2007

This article is online at http://ccforum.com/content/11/2/410

(c) 2007 BioMed Central Ltd

See related research by Gibot et al., http://ccforum.com/content/11/1/R8
Critical Care 2007, 11:410 (doi:10.1186/cc5734)
Growth arrest-specific protein 6 (GAS6) shares a high degree of similarity with protein S (PS), a cofactor for the protein $\mathrm{C}(\mathrm{PC})$ anticoagulant pathway. PS consists of an $\mathrm{N}$ terminal $\gamma$-carboxyglutamic acid (Gla) domain, a thrombinsensitive region (TSR), four epidermal growth factor-like domains and a large C-terminal sex hormone-binding globulin-like domain. The TSR loop, which is not present in GAS6, is a prerequisite for PS cofactor activity and facilitates the binding of the Gla domain of PS to the membrane phospholipids of activated platelets, endothelial cells, and platelet microparticles, where the PC anticoagulant pathway is manifested. It is predicted that GAS6 does not have a cofactor role similar to that of PS for the anticoagulant activity of activated protein C (APC) [1,2]. However, it is rather premature to exclude a possible interaction between GAS6 and PC/APC. Recent studies suggest that the PS Gla domain itself may interact directly with the Gla domain of APC on cell membrane surfaces. The Gla domains of PS and GAS6 have the highest sequence homology among all the modules. Seven out of a cluster of nine amino acid residues in the Gla domain of PS that have been identified as being of critical importance for putative binding to the APC Gla domain are identical in the GAS6 Gla domain (Leu21/Arg28/ Asn33/Asp34/Pro35/Tyr41/Leu45), whereas the other two residues are highly conserved (Asn23/Lys24 in PS; Ser23/ Arg24 in GAS6) [2,3]. The Gla domain of APC also interacts directly with the endothelial protein $C$ receptor, forming a stable complex initiating protease-activated receptor-1 (PAR-1)-dependent and PAR-1-independent PC cellular signaling pathways that are distinct from the $P C$ anticoagulant pathway and have pleiotropic cytoprotective effects. It has been recognized increasingly that the clinical success of APC for the treatment of severe sepsis is attributable, at least in part, to the PC signaling pathways.
Two recent studies revealed that the level of plasma GAS6 was elevated and was correlated with disease severity in patients with severe sepsis [4] and septic shock [5]. However, significantly different levels of plasma GAS6 between the two studies (56 to $139 \mathrm{ng} / \mathrm{ml}$ [4] and 1.5 to $164 \mathrm{pg} / \mathrm{ml}$ [5]) were reported on the basis of a similar enzyme-linked immunosorbent assay. The lack of a control group of healthy subjects in the report by Gibot and coworkers [5] prevents a direct comparison of both studies. In addition, it would be interesting to analyze the correlation between GAS6 concentrations and the outcome of APC treatment of those patients because a possible interaction between the Gla domains of GAS6 and APC might modulate the $P C$ anticoagulant and signaling pathways.

\section{Competing interests}

The author declares that they have no competing interests.

\section{References}

1. Hafizi S, Dahlback B: Gas6 and protein S. Vitamin K-dependent ligands for the Axl receptor tyrosine kinase subfamily. FEBS $J$ 2006, 273:5231-5244.

2. Manfioletti G, Brancolini C, Avanzi G, Schneider C: The protein encoded by a growth arrest-specific gene (gas6) is a new member of the vitamin K-dependent proteins related to protein $\mathrm{S}$, a negative coregulator in the blood coagulation cascade. Mol Cell Biol 1993, 13:4976-4985.

3. Saller F, Villoutreix BO, Amelot A, Kaabache T, Le Bonniec BF, Aiach M, Gandrille S, Borgel D: The $\gamma$-carboxyglutamic acid domain of anticoagulant protein $S$ is involved in activated protein C cofactor activity, independently of phospholipid binding. Blood 2005, 105:122-130.

4. Borgel D, Clauser S, Bornstain C, Bieche I, Bissery A, Remones V, Fagon JY, Aiach M, Diehl JL: Elevated growth-arrest-specific protein 6 plasma levels in patients with severe sepsis. Crit Care Med 2006, 34:219-222.

5. Gibot S, Massin F, Cravoisy A, Dupays R, Barraud D, Nace L, Bollaert PE: Growth arrest-specific protein 6 plasma concentrations during septic shock. Crit Care 2007, 11:R8.

$A P C=$ activated protein $\mathrm{C} ; \mathrm{GAS} 6=$ growth arrest-specific protein $6 ; \mathrm{Gla}=\gamma$-carboxyglutamic acid; PAR-1 $=$ protease-activated receptor-1; PC $=$ protein $\mathrm{C} ; \mathrm{PS}=$ protein $\mathrm{S} ; \mathrm{TSR}=$ thrombin-sensitive region. 